\title{
Genetic diversity of divergent redclaw crayfish Cherax quadricarinatus (Von Martens, 1868) populations evaluated to initiate a breeding program in Mexico
}

\author{
Adriana Max-Aguilar $^{1}(\mathbb{D})$, Humberto Villarreal ${ }^{1} \mathbb{D}$, Ignacio Leyva-Valencia ${ }^{2}$

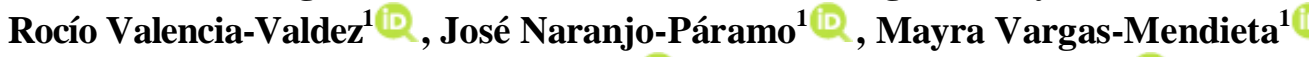 \\ Alejandra Villarreal-García ${ }^{1} \mathbb{D}$ \& Pedro Cruz-Hernández ${ }^{1}$ \\ ${ }^{1}$ Programa de Acuicultura, Centro de Investigaciones Biológicas del Noroeste S.C. \\ La Paz, B.C.S., México \\ ${ }^{2}$ Laboratorio de Zooplancton, Centro Interdisciplinario de Ciencias Marinas, La Paz, B.C.S. México \\ Corresponding author: Pedro Cruz-Hernández (pcruz@ cibnor.mx)
}

\begin{abstract}
Cherax quadricarinatus is a decapod crustacean of interest to the aquaculture industry. In Mexico, a significant effort has been made to improve biological requirements, but the genetic characteristics are unknown. We examined the genetic diversity and differentiation in four populations in Mexico (three commercial farms and one feral population), as well as one research line from Argentina, used as reference. To initiate a founder stock in a genetic improvement program, we analyzed five microsatellite markers. The genetic diversity in terms of the number of alleles was low to moderate (2.8-6.2) in Mexican populations than the Argentinean sample (8.8). A pairwise Wright's Fst analysis showed that all populations were significantly different $(P<0.5)$. Cross-breeding organisms from a different population are suggested to increase genetic variability before initiating a founder stock with higher genetic variation.
\end{abstract}

Keywords: Cherax quadricarinatus; genetic diversity; microsatellite; breeding program; aquaculture

\section{INTRODUCTION}

The redclaw crayfish Cherax quadricarinatus is a decapod crustacean of interest to the aquaculture industry for its biological characteristics (Medley et al. 1994, Jones et al. 2000). It was first introduced into Mexico in 1985 by private interests, with failed results. Later, the Federal Government introduced the species in 1995 to evaluate commercial culture's potential (Alvarez et al. 2014). Ponce-Palafox et al. (1999) mentioned that several producers received import permits, with Acuacultivos Santo Domingo in Soto La Marina, Tamaulipas, establishing one of the main stocks in 1998 (Villarreal \& Pelaez 1999). The origin of most commercial lines in Mexico can be traced back to a population from Freshwater Australian Crayfish Traders in Tarome, Queensland, Australia. The farmsourced wild broodstock from the Gilbert and Flinders Rivers in 1984 began testing the species' culture viability (Humberto Villarreal, pers. comm.). Up to
10,000 juveniles from this domesticated stock were shipped to the Tamaulipas farm in 1998 and 1999. Over the next few years, Acuacultivos Santo Domingo distributed juveniles and broodstock to several sites in Mexico, including the Northwest Biological Research Center (CIBNOR, acronym in Spanish) in La Paz, Baja California Sur, El Vergel farm in Soto La Marina, Tamaulipas, and La Alberca, a semi-intensive farm near Nueva Italia, Michoacán, geographically isolated from each other (Hernández-Gurrola et al. 2020). El Vergel farm additionally received an undetermined number of offspring from Auburn University in 20052008 to conduct research (Nabor Medina-El Vergel farm owner-, pers. comm.).

The actual number of commercial farms and production figures in Mexico is difficult to establish. Data for the species is combined with that of other freshwater crustaceans, such as freshwater prawns. However, FAO (2011) reported $50 \mathrm{t}$ of redclaw production for 2011 in the Cultured Aquatic Species Information 
Programme, produced mainly in Morelos, Tamaulipas, Sinaloa, Baja California Sur, Puebla, and Veracruz. The National Fisheries Research Institute (INAPESCA, acronym in Spanish) published guidelines for the culture of $C$. quadricarinatus in Mexico, outlining 12 laws, norms, and regulations that affected management (DOF 2013). These did no limit imports of the species into Mexico. Nevertheless, the worldwide impact of diseases in the marine shrimp, Penaeus vannamei, culture (including WSSV and the Hepatopancreatic Acute Necrosis Syndrome) resulted in a crustacean imports prohibition in 2013 (CONAPESCA 2013). The National Service for health, safety, and agri-food safety has included live crustaceans and genetic material from any species in its prohibited import list for 2020 (SENASICA 2020).

To optimize production in Mexico, a significant effort has been done to improve knowledge on the biological requirements of C. quadricarinatus, including physiological response (Carreño-León et al. 2014), reproduction (García-Guerrero et al. 2003, Rodríguez-González et al. 2014), nutritional requirements (Cortés-Jacinto et al. 2005) and production (Naranjo-Páramo et al. 2004, Nuñez-Amao et al. 2018, 2019). As indicated above, the species was introduced to the country in few events, so the risk of inbreeding is significant. At commercial farms, broodstock for next cycle juvenile production is normally obtained during grow-out pond harvests by selecting 5-10\% of the crop with the highest weight and good appearance. In the La Alberca farm in Michoacán, no size selection is carried out. Occasionally, feral organisms from local streams have been used (J. Naranjo, pers. comm.). After this selection, crosses occur randomly in reproduction ponds stocked at $1-4 \mathrm{~m}^{-2}$ and a female to male ratio of 3:1 (Naranjo-Páramo et al. 2004). It is important to notice that this artificial selection in production is not properly sustained by genetic information. As far as we know, there are no C. quadricarinatus genetic improvement programs in Mexico.

It is important to have an initial stock with broad genetic diversity to establish breeding programs. High genetic diversity is necessary to improve important economic traits such as growth, survival, or disease resistance (Davis \& Hetzel 2000, Rao \& Hodgkin 2002, Gjedrem \& Baranski 2009). Moreover, it is necessary to avoid loss of genetic variability across generations, poor genetic management, such as the use of a small number of parents, small effective population size, kinship among breeders, or inadequate or uncontrolled mating that can lead to inbreeding (Allendorf \& Ryman 1987, Gjerde et al. 1996, Gjerde \& Rye 1998, Davis \& Hetzel 2000, Doyle et al. 2001, Bentsen \& Olesen 2002).
To detect changes in variability, monitoring of genetic diversity is necessary (Allendorf \& Ryman 1987). To this end, microsatellite markers have been useful for aquacultured resources (e.g. Cruz et al. 2004, Zhu et al. 2006, Dixon et al. 2008, Sawayama \& Takagi 2016, Napora-Rutkowski et al. 2017).

Few studies have focused on the genetic diversity in C. quadricarinatus. Baker et al. (2008) detected two divergent lineages in Australia's wild stock and two different lineages in Papua, New Guinea, using mitochondrial and microsatellites markers. He et al. (2012) evaluated genetic variability in three cultured redclaw crayfish lines in China with 28 microsatellite loci and reported moderate allelic diversity and moderate divergence between them. Jerry (2013) used six microsatellite loci to evaluate genetic diversity in different lines from commercial farms in Queensland, Australia. However, there are no genetic studies of redclaw crayfish populations in Mexico. Our goal was to assess the genetic diversity of divergent redclaw crayfish populations (three from farms in different locations and one feral population from an artificial water dam). Using microsatellite markers, determine possible genetic differentiation that would contribute to developing a founder stock with a wider genetic pool, suitable for the future development of a genetic improvement program.

\section{MATERIALS AND METHODS}

\section{Sample collection}

Generation 12 adult Cherax quadricarinatus individuals (weight, $\mathrm{w}=60 \pm 5 \mathrm{~g}, \mathrm{n}=56$ ) were obtained from intensive culture $1000 \mathrm{~m}^{2}$ high-density polyethylene (HDPE) lined outdoor ponds at BioHelis, the Innovation and Technology Park at the CIBNOR in La Paz, Baja California Sur, Mexico. Redclaw crayfish $(\mathrm{w}=70 \pm 8 \mathrm{~g}, \mathrm{n}=69)$ from semi-intensive clay-bottom $1000 \mathrm{~m}^{2}$ ponds at El Vergel farm in Soto La Marina, Tamaulipas Mexico, and the Vicente Guerrero Dam ( $\mathrm{w}=77 \pm 12 \mathrm{~g}, \mathrm{n}=69)$ were collected and air-shipped to La Paz. Individuals ( $\mathrm{w}=76 \pm 7 \mathrm{~g}, \mathrm{n}=72$ ) from an extensive clay-bottom farm (La Alberca) near Nueva Italia in Michoacán were also collected and air shipped to La Paz. Tissue samples from pleopods from all individuals were preserved in $80 \%$ ethanol. For comparison purposes, 50 juveniles $(\mathrm{w}=1.5 \pm 0.5 \mathrm{~g})$ were collected and preserved in $80 \%$ ethanol from a research line recently imported from Australia at the University of Buenos Aires (UBA) in Argentina before shipped to CIBNOR. Further information on sampled populations is presented (Table 1). 
Table 1. General information from populations of Cherax quadricarinatus evaluated in Mexico. A population recently introduced from Australia to Argentina was included as a reference. *Feral populations were established after accidental or intentional releases from local commercial farms. **According to Telchea \& Fontaine (2014); 0: capture fisheries; 1: first trials of acclimatization to the culture environment; 2: part of the life cycle is completed in captivity, but several important bottlenecks still exist in others (e.g. reproduction, larval rearing); 3: the entire cycle is closed in captivity, but with wild inputs; 4: the whole life cycle is closed in captivity without wild inputs, but no selective breeding program is used; 5 : a selective breeding program is used. UBA: University of Buenos Aires. CIBNOR: Northwest Biological Research Center.

\begin{tabular}{|c|c|c|c|c|c|}
\hline Population & Location & Coordinates & Facilities & Culture Level & $\begin{array}{c}\text { Domestication } \\
\text { level }\end{array}$ \\
\hline CIBNOR & La Paz, BCS & $24^{\circ} 08^{\prime} 05^{\prime \prime} \mathrm{N}, 110^{\circ} 25^{\prime} 41^{\prime \prime} \mathrm{W}$ & Pilot Scale & Intensive & 4 \\
\hline La Alberca & Nueva Italia, Michoacán & $18^{\circ} 52^{\prime} 27^{\prime \prime} \mathrm{N}, 102^{\circ} 06^{\prime} 39^{\prime \prime} \mathrm{W}$ & Farm & Extensive & 2 \\
\hline Vicente Guerrero & Padilla, Tamaulipas & 235'ㄱ'34"N, 98³9'57"W & Dam & Feral population* & 0 \\
\hline El Vergel & Soto La Marina, Tamaulipas & $23^{\circ} 45^{\prime} 20^{\prime \prime} \mathrm{N}, 98^{\circ} 12^{\prime} 10^{\prime \prime} \mathrm{W}$ & Farm & Semi-intensive & 4 \\
\hline UBA & Buenos Aires & $34^{\circ} 35^{\prime} 59^{\prime \prime} \mathrm{S}, 58^{\circ} 22^{\prime} 23^{\prime \prime} \mathrm{W}$ & Research & Experimental & 3 \\
\hline
\end{tabular}

\section{Genetic analysis}

Total DNA in all tissue samples was extracted with phenol-chloroform-isoamyl alcohol, following the protocol described by Wasko et al. (2003). Five microsatellite loci (Baker et al. 2000) were analyzed: CQU.0001, CQU.002, CQU.003, CQU.004, and CQU.006. Microsatellites were amplified by PCR in a 12.5 volume containing: $2 \mu \mathrm{l}$ DNA, $1 \mathrm{X}$ Taq buffer, $3 \mathrm{mM} \mathrm{MgCl} 2,0.2 \mathrm{mM}$ dNTPs, $0.2 \mu \mathrm{M}$ of each primer Forward and Reverse, $0.02 \mathrm{U}_{\mu \mathrm{L}^{-1}}$ Taq polymerase (Invitrogen). PCR thermal conditions were $4 \mathrm{~min}$ at $94^{\circ} \mathrm{C}$ of initial denaturation; continued by 33 cycles of $1 \mathrm{~min}$ at $94^{\circ} \mathrm{C}, 1 \mathrm{~min}$ at $55^{\circ} \mathrm{C}, 2 \mathrm{~min}$ at $72^{\circ} \mathrm{C}$, and a final extension of $10 \mathrm{~min}$ at $72^{\circ} \mathrm{C}$. PCR products were separated by electrophoresis in a $5 \%$ acrylamide $7.5 \mathrm{M}$ urea gel; the alleles were visualized with Sybr Gold 10,000x (Invitrogen) in an FMBIO III scanner (Hitachi).

The number of alleles $(\mathrm{Na})$, effective number of alleles $(\mathrm{Ne})$, observed and expected heterozygosity (Ho and $\mathrm{He}$ ), inbreeding coefficient (Fis), and allele frequencies were estimated with GenAlEx 6.503 (Peakall \& Smouse 2012). Genetic differences between lines, measured as Wright's Fst values, were calculated by Arlequin 3.5 (Excoffier \& Lischer 2010). The statistical significance of each comparison was estimated through 10,000 permutation procedures. Also, we used GenAlEx 6.503 (Peakall \& Smouse 2012) to calculate a pairwise genetic distance matrix and then converted it to a covariance matrix to perform a principal coordinate analysis (PCoA). Further, we perform an AMOVA with 999 permutations to estimated genetic variation between and within the population. We used organisms with a minimum of four genotyped loci microsatellites; individuals with two or more missing data were discarded.

\section{RESULTS}

A genetic diversity value for all groups is summarized in Table 2. Na ranged from 2.8-8.8 and Ne from 1.5883.944; in both cases, the UBA group showed a higher number of alleles and presented higher $\mathrm{Ho}$ and $\mathrm{He}$ values ( 0.600 and 0.695 , respectively). For Mexico, the El Vergel group had a higher $\mathrm{Na}$ (6.2), and Vicente Guerrero had a higher $\mathrm{Ne}$ (3.219). CIBNOR showed the lowest diversity. The Fis values were 0.081 to 0.193 ; UBA showed the lowest Fis and La Alberca's highest value.

Allele frequencies (Fig. 1) revealed private alleles and different allele frequencies in the groups, mainly for locus CQU.006. For locus CQU.001 and CQU.002, similar alleles and frequencies were shown in all groups, except for UBA.

Genetic differentiation analysis based on pairwise Fst (Table 3) showed that all lines are statistically different Fst $(P<0.05)$. The highest degree of differentiation occurred between CIBNOR and UBA (0.33213). On the other hand, the lowest degree of differentiation occurred between La Alberca and El Vergel (0.04662), followed by El Vergel and Vicente Guerrero (0.08270). In general, CIBNOR presented the greatest Fst values when compared to the other Mexican groups.

Principal coordinate analysis (PCoA) (Fig. 2) confirmed the genetic differences among individuals from CIBNOR and, as expected, from UBA. The accumulated percentage of variation explained by the three first axes was $33.61 \%$. The first axis explained $13.05 \%$, the second $10.60 \%$, and the third $9.96 \%$. The AMOVA results showed a percentage of molecular variance of $15 \%$ among populations, $26 \%$ between individuals, and $59 \%$ within individuals. 
Table 2. Genetic diversity of Cherax quadricarinatus from populations in Mexico. n: number of individuals analyzed, Na: average number of alleles, Ne: effective number of alleles, Ho: observed heterozygosity, He: expected heterozygosity, Fis: inbreeding coefficient. A recently introduced population from Australia to Argentina was included for reference values. UBA: University of Buenos Aires. CIBNOR: Northwest Biological Research Center.

\begin{tabular}{lcccccc}
\hline & $\mathrm{n}$ & $\mathrm{Na}$ & $\mathrm{Ne}$ & $\mathrm{Ho}$ & $\mathrm{He}$ & Fis \\
\hline CIBNOR & 56 & 2.8 & 1.588 & 0.321 & 0.357 & 0.095 \\
La Alberca & 66 & 4.0 & 1.948 & 0.355 & 0.466 & 0.193 \\
Vicente Guerrero & 59 & 5.4 & 3.219 & 0.419 & 0.553 & 0.159 \\
El Vergel & 64 & 6.2 & 2.927 & 0.467 & 0.595 & 0.186 \\
\hline UBA & 33 & 8.8 & 3.944 & 0.600 & 0.695 & 0.081 \\
\hline
\end{tabular}
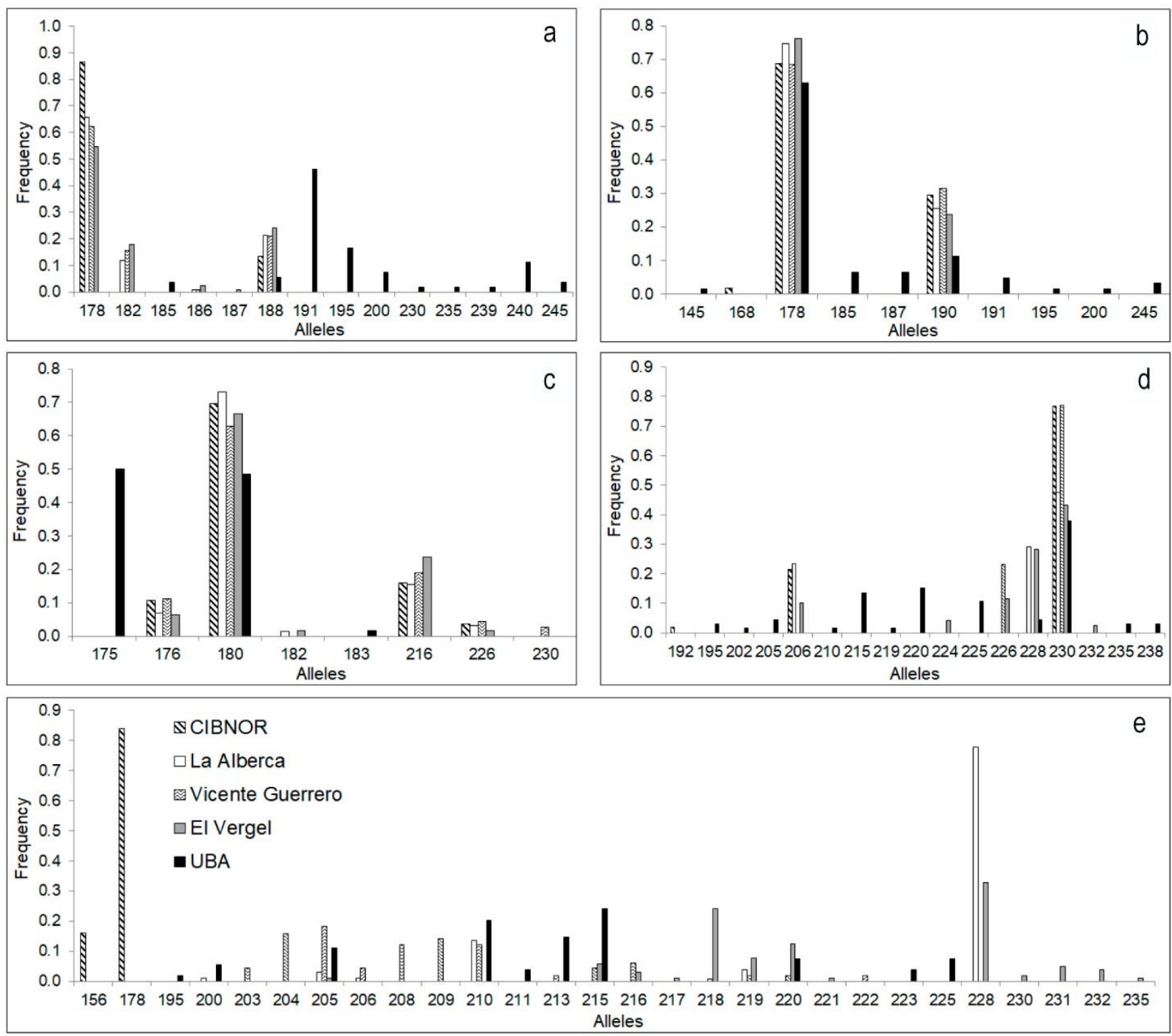

Figure 1. Allele frequencies for the five microsatellite loci in Cherax quadricarinatus populations. a) Locus CQU.001, b) locus CQU.002, c) locus CQU.003, d) locus CQU.004, e) locus CQU.006. Northwest Biological Research Center $($ CIBNOR) $n=56$; La Alberca $n=66$; Vicente Guerrero $n=59$; El Vergel $n=64 ;$ UBA; University of Buenos Aires (UBA) $\mathrm{n}=33$. 
Table 3. Pairwise population Fst values for divergent Cherax quadricarinatus populations. All pairwise Fst values are statistically significant $(P<0.05)$. UBA: University of Buenos Aires. CIBNOR: Northwest Biological Research Center.

\begin{tabular}{lccccc}
\hline & CIBNOR & La Alberca & Vicente Guerrero & El Vergel & UBA \\
\hline CIBNOR & $*$ & & & & \\
La Alberca & 0.25328 & $*$ & & & \\
Vicente Guerrero & 0.20161 & 0.14015 & $*$ & & \\
El Vergel & 0.21585 & 0.04662 & 0.08270 & $*$ & \\
UBA & 0.33213 & 0.23926 & 0.17259 & 0.17299 & $*$ \\
\hline
\end{tabular}

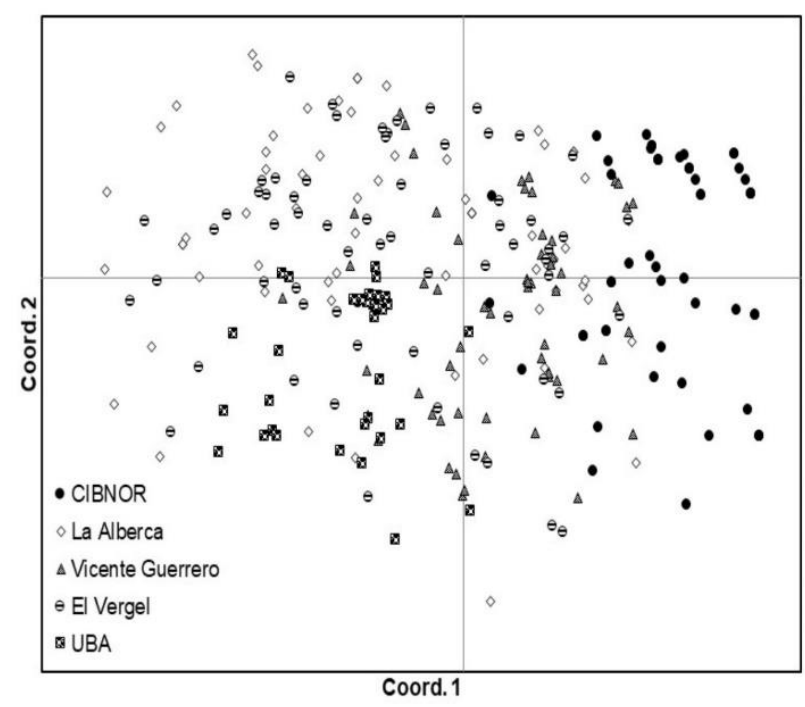

Figure 2. Principal coordinate analysis (PCoA) plot for different Cherax quadricarinatus populations in Mexico. A recently introduced population from Australia to Argentina was included as a reference. UBA: University of Buenos Aires, CIBNOR: Northwest Biological Research Center.

\section{DISCUSSION}

In our study, Na's terms' genetic variability was from low to moderate (2.8-6.2) for the divergent groups in Mexico, with an average of 4.6 alleles. The mean value for UBA was 8.8 , which is probably related to a more recent translocation event, with a potential different bottleneck effect and subsequent genetic drift or a more efficient management strategy to prevent the loss of genetic variability. The moderate genetic variability in the Mexican lines agrees with previous reports in cultured lines of the redclaw in Australia and China (He et al. 2012, Jerry 2013) and is lower than that reported for Australian and Papua New Guinean wild stocks (Baker et al. 2008) that ranged from 11 to 40 alleles.

Jerry (2013) analyzed the genetic variability in eight Australian farms and the "Walkamin" genetic line (Jones et al. 2000) from the Queensland Department of Primary Industries (QDPI), using six microsatellite loci from Baker et al. (2000), evaluating the results for the five microsatellite loci we used, the Na ranged from 2.5 to 7, similar to our study results ( $\mathrm{Na} 2.8-6.2)$. He et al. (2012) reported a range of 2.96 to 3.25 alleles for three cultured lines in China, using 28 microsatellite loci, which is similar to the results for CIBNOR (Na 2.8). Ho in our study (0.321-0.600) was within the range of Australian farms (0.32-0.78; Jerry 2013) and lower than the report of He et al. (2012) for China (0.65-0.68). Significantly, wild stocks' values ranged from 0.35 to 0.71 (Baker et al. 2008), showing high variability. It is important to state that heterozygosity is not a perfect genetic variation indicator (Cruz et al. 2004). It is not sensitive to Na since high values with as few as two alleles can be obtained (Beardmore et al. 1997). A more appropriate evaluation of genetic variability must consider both $\mathrm{Na}$ and Ho to avoid risky or erroneous conclusions. In terms of genetic variation, the Mexican lines have moderate genetic variation, enough to proceed to a cross-mating design that generates a broodstock nucleus with wider genetic variation, as was previously done in Australia (Jerry 2013).

The genetic differentiation analysis showed that all lines were statistically different based on pairwise Fst $(P<0.5)$, despite the common events of introduction in the case of Mexico (Ponce-Palafox et al. 1999), with a similar origin two decades ago. It possibly indicates a differential effect of the genetic drift, different effective number of breeders, and directed or non-directed breeding. CIBNOR showed the larger Fst values, particularly when compared with UBA (0.33213). The PCoA plot shows a tendency in which individuals from CIBNOR separate from individuals from other groups. CIBNOR is the only group properly domesticated for the Mexican lines, managed and studied, with reported intentions of developing a nucleus with wide variability that leads to a genetic selection program (MoraCastrejón 2019).

Despite being considered a feral population, crayfish from the Vicente Guerrero dam showed similar diversity to the nearby El Vergel farm and lower than the Argentinean sample. Though $C_{\text {. quadricarinatus_is }}$ susceptible to escapes from captivity due to its ability to climb and move out of the water (Jones et al. 2000), the source of the feral population in Vicente Guerrero 
dam is probably the intentional releases from nearby farms (Mendoza-Alfaro et al. 2011). Pairwise Fst analysis showed the low genetic distance between El Vergel farm and the Vicente Guerrero dam (0.08270), both in Tamaulipas.

CIBNOR showed the lowest diversity, underlining the need to increase genetic diversity. Inbreeding accumulates over time in cultured populations since related individuals will mate, even with best management practices securing random pairings (Andersen \& Hayes 2005). Improper husbandry can accelerate the loss of genetic variation. Considering that, the overall objective of evaluating diverging lines is to establish a founder stock with wider genetic variation and significant capacity for domesticated management in aquaculture systems. The results of genetic variation and previous production performance (Hernández-Gurrola et al. 2020) reveal that the CIBNOR (generation 12) line is appropriate for founder stock cross-breeds with individuals from the other evaluated lines in Mexico.

\section{ACKNOWLEDGMENTS}

We acknowledge the technical assistance of Susana Ávila-Álvarez, Héctor Acosta-Salmón, and Jesús Aguilar of CIBNOR. Laura López-Greco at the University of Buenos Aires provided the samples from Argentina. This work was funded by Finnova Project \#173520 and SEP-CONACYT Project \#242683 to Humberto Villarreal. Rocío Valencia and Alejandra V. Villarreal are recipients of MSc scholarships from the Consejo Nacional de Ciencia y Tecnología (CONACYT). Two anonymous reviewers provided valuable comments on a draft of this manuscript.

\section{REFERENCES}

Allendorf, F.W. \& Ryman, N. 1987. Genetic management of hatchery stocks. In: Ryman, N. \& Utter, F. (Eds.). Population genetics and fishery management. University of Washington Press, Seattle, pp. 141-159.

Alvarez, F., Bortolini, J.L., Villalobos, J.L. \& García, L. 2014. La presencia del acocil australiano Cherax quadricarinatus (Von Martens, 1868) en México. In: Low-Pfeng, A.M., Quijón, P.A. \& Peters-Recagnos, E.M. (Eds.). Especies invasoras acuáticas: casos de estudio en ecosistemas de México. Secretaría de Medio Ambiente y Recursos Naturales, México D.F., pp. 603-622.

Andersen, O. \& Hayes, B. 2005. Population genetics. In: Gjedrem, T. (Ed.). Selection and breeding programs in aquaculture. Springer, Amsterdam, pp. 23-33.
Baker, N., De Bruyn, M. \& Mather, P.B. 2008. Patterns of molecular diversity in wild stocks of redclaw crayfish (Cherax quadricarinatus) from northern Australia and Papua New Guinea: impacts of Plio-Pleistocene landscape evolution. Freshwater Biology, 53: 15921605.

Baker, N., Byrne, K., Moore, S. \& Mather, P. 2000. Characterization of microsatellite loci in the redclaw crayfish, Cherax quadricarinatus. Molecular Ecology, 9: 494-495.

Beardmore, J.A., Mair, G.C. \& Lewis, R.I. 1997. Biodiversity in aquatic systems in relation to aquaculture. Aquaculture Research, 28: 829-839.

Bentsen, H.B. \& Olesen, I. 2002. Designing aquaculture mass selection programs to avoid high inbreeding rates. Aquaculture, 204: 349-359.

Carreño-León, D., Racotta-Dimitrov, I., CasillasHernández, R., Monge-Quevedo, A., OcampoVictoria, L., Naranjo-Páramo, J. \& Villarreal, H. 2014. Growth, metabolic and physiological response of juvenile Cherax quadricarinatus fed different available nutritional substrates. Journal of Aquaculture Research \& Development, 5: 1-7.

Comisión Nacional de Acuacultura y Pesca (CONAPESCA). 2013. Amplía SAGARPA la restricción de importación de crustáceos de cuatro países de Asia. [https://www.gob.mx/conapesca/prensa/amplia-sagarpala-restriccion-de-importacion-de-crustaceos-de-cuatropaises-de-asia]. Reviewed: November 30, 2020.

Cortés-Jacinto, E., Villarreal-Colmenares, H., CruzSuárez, L.E., Civera-Cerecedo, R., Nolasco-Soria, H. \& Hernández-Llamas, A. 2005. Effect of different dietary protein and lipid levels on growth and survival of juvenile Australian redclaw crayfish, Cherax quadricarinatus (von Martens). Aquaculture Nutrition, 11: 283-291.

Cruz, P., Ibarra, A.M., Mejia-Ruiz, H., Gaffney, P.M. \& Pérez-Enríquez, R. 2004. Genetic variability assessed by microsatellites in a breeding program of Pacific white shrimp (Litopenaeus vannamei). Marine Biotechnology, 6: 157-164.

Davis, G.P. \& Hetzel, D.J.S. 2000. Integrating molecular genetic technology with traditional approaches for genetic improvement in aquaculture species. Aquaculture Research, 31: 3-10.

Dixon, T.J., Coman, G.J., Arnold, S.J., Sellars, M.J., Lyons, R.E., Dierens, L., et al. 2008. Shifts in genetic diversity during domestication of black tiger shrimp, Penaeus monodon, monitored using two multiplexed microsatellite systems. Aquaculture, 283: 1-6. 
Diario Oficial de la Federación (DOF). 2013. INAPESCA. Langosta de agua dulce. Carta Nacional Acuícola. Diario Oficial de la Federación 9 de septiembre de 2013, Mexico D.F., pp. 21-24.

Doyle, R.W., Pérez-Enríquez, R., Takagi, M. \& Taniguchi, N. 2001. Selective recovery of founder genetic diversity in aquacultural broodstocks and captive, endangered fish populations. Genetica, 111: 291-304.

Excoffier, L. \& Lischer, H.E.L. 2010. Arlequin suite ver. 3.5: a new series of programs to perform population genetics analyses under Linux and Windows. Molecular Ecology Resources, 10: 564-567.

Food and Agriculture Organization (FAO). 2011. Cultured aquatic species information programme. Cherax quadricarinatus. [http://www.fao.org/fishery/ culturedspecies/Cherax_quadricarinatus/en]. Reviewed: November 30, 2020.

García-Guerrero, M., Villarreal, H. \& Racotta, I.S. 2003. Effect of temperature on lipids, proteins, and carbohydrates levels during development from egg extrusion to juvenile stage of Cherax quadricarinatus (Decapoda: Parastacidae). Comparative Biochemistry and Physiology - Part A: Molecular \& Integrative Physiology, 135: 147-154.

Gjedrem, T. \& Baranski, M. 2009. Selective breeding in aquaculture: an introduction. Springer, London.

Gjerde, B. \& Rye, M. 1998. Design of breeding programmes in aquaculture species: possibilities and constraints. In: Bartley, D.M. \& Basurco, B. (Eds.). Genetics and breeding of Mediterranean aquaculture species. CIHEAM Zaragoza, Zaragoza, pp. 181-192.

Gjerde, B., Gjøen, H.M. \& Villanueva, B. 1996. Optimum designs for fish breeding programmes with constrained inbreeding mass selection for a normally distributed trait. Livestock Production Science, 47: 5972.

He, L., Xie, Y., Lu, W., Wang, Y., Chen, L., Mather, P.B., et al. 2012. Genetic diversity in three redclaw crayfish (Cherax quadricarinatus, von Martens) lines developed in culture in China. Aquaculture Research, 43: 75-83.

Hernández-Gurrola, J.A., Naranjo-Páramo, J., VargasMendieta, M., Cruz-Hernández, P., Villarreal-García, A., Mora-Castrejón, G. \& Villarreal-Colmenares, H. 2020. Effect of crossbreeding three divergent populations on the juvenile production and rearing performance of the redclaw crayfish Cherax quadricarinatus. Aquaculture, 527: 735420

Jerry, D. 2013. Genetic improvement of redclaw growth through targeted selection. In: Stevenson, J., Jerry, D. \& Owens, L. (Eds.). Redclaw selective breeding project. Australian Government RIRDC Publication 13/007, pp. 18-26.
Jones, C.M., McPhee, C.P. \& Ruscoe, I.M. 2000. A review of genetic improvement in growth rate in redclaw crayfish Cherax quadricarinatus (von Martens) (Decapoda: Parastacidae). Aquaculture Research, 31: 61-67.

Medley, P.B., Jones, C.M. \& Avault, J.A. 1994. A global perspective of the culture of Australian redclaw crayfish, Cherax quadricarinatus: production, economics and marketing. Journal of the World Aquaculture Society, 25: 6-13.

Mendoza-Alfaro, R.E., Rodríguez-Almaraz, G.A. \& Castillo-Alvarado, S.A. 2011. Riesgo de dispersión y posibles impactos de los acociles australianos del género Cherax en México. Comisión Nacional para el Conocimiento y Uso de la Biodiversidad, Mexico D.F.

Mora-Castrejón, G. 2019. Caracterización del desarrollo de un pie de cría de la langosta de agua dulce Cherax quadricarinatus con elevada variabilidad genética. Tesis de Maestría, Instituto Politécnico Nacional, Baja California Sur.

Naranjo-Páramo, J., Hernández-Llamas, A. \& Villarreal, H. 2004. Effect of stocking density on growth, survival and yield of juvenile redclaw crayfish Cherax quadricarinatus (Decapoda: Parastacidae) in gravellined commercial nursery ponds. Aquaculture, 242: 197-206.

Napora-Rutkowski, L., Rakus, K., Nowak, Z., Szczygiel, J., Pilarczyk, A., Ostaszewska, T. \& Irnazarow, I. 2017. Genetic diversity of common carp (Cyprinus carpio L.) strains breed in Poland based on microsatellite, AFLP, and mtDNA genotype data. Aquaculture, 473: 433-442.

Nuñez-Amao, L., Villarreal, H., Naranjo-Páramo, J. \& Hernández-Llamas, A. 2018. Stochastic analysis of production dynamics of male and female redclaw crayfish (Cherax quadricarinatus) reared under commercial intensive cultivation. Reviews in Aquaculture, 10: 439-450.

Nuñez-Amao, L., Naranjo-Páramo, J., HernándezLlamas, A., Vargas-Mendieta, M. \& Villarreal, H. 2019. Estimating production costs of preadult redclaw crayfish, Cherax quadricarinatus, reared in a commercial nursery system: a stochastic bioeconomic approach. Journal of the World Aquaculture Society, 50: $172-185$.

Peakall, R. \& Smouse, P.E. 2012. GenAlEx 6.5: genetic analysis in Excel. Population genetic software for teaching and research-an update. Bioinformatics, 28: 2537-2539.

Ponce-Palafox, J.T., Arredondo-Figueroa, J.L. \& Romero, X. 1999. Análisis del cultivo comercial de la langosta de agua dulce (Cherax quadricarinatus): y su posible impacto en América Latina. Contactos, 31: 54-61. 
Rao, V.R. \& Hodgkin, T. 2002. Genetic diversity and conservation and utilization of plant genetic resources. Plant Cell, Tissue and Organ Culture, 68: 1-19.

Rodríguez-González, H., Hernández-Llamas, A., GarcíaUlloa, M., Racotta, I.S., Montoya-Mejía, M. \& Villarreal, H. 2014. Effect of protein and lipid levels in diets for female redclaw crayfish Cherax quadricarinatus on quality of offspring (juvenile), with emphasis on growth performance, biochemical composition and stress resistance to low oxygen, high ammonia and salinity. Aquaculture Nutrition, 20: 557565.

Sawayama, E. \& Takagi, M. 2016. Genetic diversity and structure of domesticated strains of red sea bream, Pagrus major, inferred from microsatellite DNA markers. Aquaculture Research, 47: 379-389.

Servicio Nacional de Sanidad, Inocuidad y Calidad Agroalimentaria (SENASICA). 2020. Productos prohibidos. [https://www.gob.mx/senasica/documentos/ productos-prohibidos?state=published]. Reviewed: November 30, 2020.

Received: August 28, 2020, Accepted: December 3, 2020
Teletchea, F. \& Fontaine, P. 2014. Levels of domestication in fish: implications for the sustainable future of aquaculture. Fish and Fisheries, 15: 181-195.

Villarreal, H. \& Pelaez, J. 1999. Biología y cultivo de langosta de agua dulce, Cherax quadricarinatus. Manual de producción. Centro de Investigaciones Biológicas del Noroeste S.C. - Acuacultivos Santo Domingo, Baja California Sur.

Wasko, A.P., Martins, C., Oliveira, C. \& Foresti, F. 2003. Non-destructive genetic sampling in fish. An improved method for DNA extraction from fish fins and scales. Hereditas, 138: 161-165.

Zhu, Z.Y., Lin, G., Lo, L.C., Xu, Y.X., Feng, F., Chou, R. \& Yue, G.H. 2006. Genetic analyses of Asian seabass stocks using novel polymorphic microsatellites. Aquaculture, 256: 167-173. 